\title{
KESUAMAN: BAHAYA LATEN TERHADAP KEHIDUPAN GEREJA TUHAN
}

\author{
Oleh: Dr. Stephanus Hartoyo ${ }^{1}$
}

\begin{abstract}
Lukewarmness is a latent, serius and contagious spriritual sickness that keeps happening in a regularly repeated order - a cycle in the life of the believers in God as well as the Church. The Bible has all the records about it. The life of the Israelites and even the Church of Christ in its history, portray vividly how lukewarmness had been taking place over and over again. The world with all its attractions has dazzled the eyes of the Christians, so they focus and run for wealth and depise their spiritual needs. When their lives are care free, and complacent, they do not have time for God, or for the Church, and eventually, the church disappeares. The answer to the above condition is to do discipleship ministry consistently to the Christians so they become Christ-like disciples, freed from biblical illiteracy, and the lost of spiritual vitality. Christianity is not just a matter of confession, but a way of life in any situation, a full devotion to God.
\end{abstract}

\begin{abstract}
Kesuaman adalah penyakit rohani yang tidak kasat mata, serius dan menular yang selalu terjadi seperti suatu siklus dalam kehidupan umat percaya dan gereja Tuhan. Alkitab mencatat dan menjelaskan semuanya itu. Sejarah kehidupan bangsa Israel dan bahkan gereja Tuhan memaparkan dengan jelas bahwa kesuaman itu selalu terjadi berulang-ulang. Dunia kita dengan segala kemewahan dan daya tariknya telah menyilaukan mata orang percaya, sehingga mereka memfokuskan mata dan mengejar kekayaan dunia serta mengabaikan kebutuhan rohani, yang pada akhirnya mematikan Gereja Tuhan. Solusi terhadap masalah ini utamanya adalah pelayanan pemuridan terhadap umat percaya sehingga mereka menjadi murid-murid yang serupa dengan Kristus, yang terbebas dari kebutaan rohani, dan tidak kehilangan vitalitas spiritual. Kekristenan itu bukan hanya sebuah pengakuan percaya, kekristenan adalah sebuah gaya hidup yang dihayati dalam segala situasi, sebagai suatu bakti yang tulus kepada Tuhan.
\end{abstract}

\footnotetext{
${ }^{1}$ Penulis adalah Dosen di Prodi Pasca Sarjana Sekolah Tinggi Teologi Nazarene Indonesia
} 


\section{Pendahuluan \& Penjelasan Istilah}

Sebagai seorang dosen yang juga berkecimpung sangat lama dalam dunia pastoral ministry dan pastoral leadership, maka penulis telah banyak mengamati dan bahkan mendalami situasi kehidupan umat Kristen dan gereja Tuhan dari sudut perjalanan imannya. Sangat jelas teramati oleh penulis bahwa bahaya yang paling besar dan harus diwaspadai oleh para pemimpin Gereja Tuhan adalah apa yang namanya kesuaman. Kesuaman itu suatu realita yang sangat sering disembunyikan, dan sesungguhnya hal itu mudah disembunyikan, Ralph Earl menyebut kesuaman sebagai "heart trouble." 2 Apabila hal itu tidak diatasi, maka orang yang mengalami kesuaman bukan saja akhirnya hilang dari jemaat Gereja, malah kadang juga meninggalkan persoalan tersendiri bagi jemaat tersebut.

Kesuaman itu seperti musuh dalam selimut, sering tidak disadari, sering diabaikan oleh yang mengalami, bahkan oleh para pelayan Tuhan. Kesuaman adalah seatu penyakit dengan prevalensi yang tinggi, seperti penyakit menular yang merasuk dalam kehidupan iman orang percaya. Itulah sebabnya penulis mengangkat tema ini untuk dipahami, digumuli untuk sekaligus bisa dicegah oleh khususnya para pelayan Gereja Tuhan.

Perlu dijelaskan mengapa penulis memakai istilah laten (latent) yang berarti tersembunyi, atau kurang tampak jelas adalah karena menurut penulis kesuaman itu sering bersembunyi dibalik banyak fenomena kehidupan umat, misalkan kesibukan, kekayaan, kekecewaan, kepenatan hidup dan sebagainya.

\section{Pembahasan}

\section{Metode Penelitian}

Penelitian ini akan mengkombinasikan studi eksposisi kitab Hakim-hakim 2:6-23 \& Wahyu 3:14-22) serta wawancara beberapa pendeta Gereja Kristen Nazarene di Indonesia. Artinya bahwa temuan eksposisi itu dikaitkan dengan apa yang diamati, diselidiki \& dialami oleh para pendeta tersebut, supaya tulisan ini menjadi relevan. Yang dimaksud eksposisi adalah suatu penelitian teks Alkitab yang digali sedemikaian rupa untuk menemukan makna yang sesungguhnya. Kata eksposisi berasal dari kata bahasa Inggris sebagai berikut. "Exposition n. expounding or explaining." 3 Itu berarti bahwa teks tersebut digali, dipahami dan diuraikan intinya dengan memperhatikan unsur-unsur gramatikal, konteks dan historisnya untuk menemukan makna sesuai dengan maksud penulis teks tersebut. Dua bagian teks yang dieksposisi mempunyai kesamaan kondisi, walapun istilah yang dipakai berbeda. Apa itu kesuaman

${ }^{2}$ Ralph Earle, Beacon Commentary, Vol. 10, The Book of Revelation, (Kansas City: Beacon Hill Press of Kansas City, 1967), 524.

${ }^{3}$ A.S. Hornby, E.V. Gatenby; H. Wakefield, The Advanced Learner's Dictionary of Current English (London: The English Language Book Society and Oxford University Press, 1962), 316, 317 
Kesuaman menurut kamus bahasa Indonesia "hangat," tidak panas, tidak dingin. ${ }^{4}$ Dalam konteks hidup iman Kristen, makna figuratifnya adalah suatu kondisi orang yang tetap pada pengakuan sebagai Kristen, tetapi tidak ada penghayatan \& komitmen hidup selaku orang Kristen. Ada yang menyebut sebagai "Kristen kuburan" artinya dilihat dari hidupnya orangorang di sekitarnya tidak tahu bahwa dia adalah orang Kristen, tahunya waktu meninggal dikuburkan di makam Kristen. Dalam bahasa Inggris kesuaman: lukewarmness, adj. moderately warm, neither very warm nor cold. 2. (fig) not deeply interested, not eager either in supporting or opposing ${ }^{5}$ Kesuaman dalam konteks bahasan ini adalah suatu kondisi kehidupan iman yang karena sesuatu hal, menjadi tdak ada gairah dan komitmen, tidak menyatakan ketidak percayaan, juga tidak menyatakan ketidak percayaannya, tetapi kekristenannya diwarnai oleh sikap acuh tak acuh.

Maknanya bahwa sebagai umat Kristen yang menyembah TUHAN Yahweh, tetap pada pengakuannya, tetapi tidak ada bukti nyata yang memberikan indikasi bahwa yang bersangkutan adalah orang Kristen. Kondisi itu disebut oleh Ralph Earle dengan istilah dead orthodoxy ${ }^{6}-$ ortodoksi yang mati. Salah seorang yang kami wawancarai menyebutnya dengan iman yang mati, Kristen tanpa tanda-tanda kehidupan. Being lukewarm is saying that you are in a right relationship with God but living like you don't. And God hates this. ${ }^{7}$ Sesungguhnya, kesuaman itu berkaitan erat dengan komitmen, dengan kasih kepada Tuhan, dan juga berkaitan dengan pemahaman yang utuh tentang apa artinya menjadi orang Kristen. Roh yang menyala-nyala (spiritual fervor) dan kehidupan nyata yang berbuah kebenaran tidak tampak, tidak ada.

Adam Clarks menjelaskan keadaan itu dengan ungkapan: ... neither heathens nor Christiansneither good nor evil-either led away by false doctrine nor thoroughly addicted to that which is true.... they were listless and indifferent, and seemed to care little weather heathenism nor Christianity prevailed. ${ }^{8}$ Kesuaman adalah gejala awal, seperti penyakit kanker stadium satu, dan bila dibiarkan akan menjadi makin parah dan menuju kepada kemurtadan iman.

\section{Mengapa Menjadi Suam?}

Berkaca dari kisah bangsa Israel paska Yosua, kita melihat bahwa dalam periode itu telah terjadi suatu situasi yang amat berbeda secara social, politik dan ekonomi. Secara politik, Israel telah mendapatkan sebuah derajat baru, dari bangsa budak bertahun-tahun di Mesir, kemudian nomadis selama lebih dari 40 tahun, dan akhirnya atas pimpinan Yosua mereka bisa memiliki negeri sendiri.

Konsekuansi logis dari hal di atas, maka umat Israel secara ekonomi juga menjadi mapan dan makmur- complacent, self satisfied. Mengacu kepada janji Tuhan, maka mereka

\footnotetext{
${ }^{4}$ WJS Poerwodarminta, Kamus Umum bahasa Indonesia, (Jakarta, Balai Pustaka,1987), 966

5 A.S. Hornby dkk, 587

${ }^{6}$ Ralp Earle, 524,

${ }^{7}$ Christina Paterson, 3 Signs You Might be a Lukewarm Christian, WWW.ibelieve.com, Feb. 15, 2017.

${ }^{8}$ Adam Clarke, The Holy Bible, Old and New Testament: Commentary \& Critical Notes, Vol. VI.(London:Ward, Lock \& Co., Warwick House,tt), Tafsir Wahyu 3:15, th.
} 
mendapatkan rumah-rumah dari bangsa yang mereka halau. Mereka juga mendapatkan kebun anggur, pohon-pohon zaitun dan ladang-ladang penggembalaan, semuanya gratis. Tentunya juga mereka mendapatkan jarahan yang tidak terhingga, sesuai dengan konteks perang pada zaman itu. Dengan kata lain, mereka makmur, hidup tentram dan bebas dari ketakutan dan kekuatiran masa depan. Mereka memasuki zona baru, zona nyaman sampai melupakan Dia yang mengaruniakan semua berkat dan rahmat itu. Mereka berbalik dan keliru sebab mereka memindahkan kasihnya dari sang pemberi berkat kepada berkat itu sendiri. Kekayaan atau mammon menjadi jerat yang memperdaya hidup imannya sebagai umat TUHAN Yahweh. Mereka menjadi suam dan kemudian berujung kepada suatu kondisi hidup yang berpaling dari Tuhan, terseret perilaku dan penyembahan bangsa-bangsa di sekitar mereka, suatu perilaku yang bertentangan dengan ketetapan Tuhan.

Sedangkan dalam kitab Wahyu 3:14-22, kita juga membaca tentang suatu jemaat di Laodekia dimana kesuaman yang mereka tampilkan digambarkan sebagai tidak panas, tidak dingin. Barangkali mereka tidak meninggalkan iman, dan mereka merasa masih beriman, juga mereka merasa kaya. Bahkan Firman Tuhan mengatakan bahwa jika kondisi itu tdk diperbaiki, maka Tuhan akan memuntahkan mereka (Wah. 3:16)

Kenyamanan membuat orang menjadi lengah, kurang bersandar pada Tuhan, sebab segalanya ada. Keadaan yang damai dan bebas kekuatiran membuat kurang ibadahnya, kurang doanya, kurang imannya, hilang komitmennya. Mengapa harus ke gereja dan meneduhkan diri? Rasa hati sudah teduh, harta terasa cukup, perut kenyang, hati senang, dan jiwanya tenang. Tuhan itu Allah masa lalu, He is God of yesterday, good \& great in the past, but not today! Seperti orang kaya dalam perumpamaan Yesus, yang sudah bisa merombah gudangnya menjadi jauh lebih besar, dan dalam complacencynya, ia berkata: "Jiwaku, ada padamu banyak barang, tertimbun untuk bertahun-tahun lamanya, beristirahatlah, makanlah, minumlah dan bersenangsenanglah!" (Luk. 12:19)

Akibat dari berubahnya "status ekonomi \& politik" yang tiba-tiba dan sangat baik itu, maka umat Israel menjadi sibuk dengan urusan kehidupan sesehari, sibuk dengan rumahnya, kebun anggurnya, ladangnya, kebun zaitunnya. Seluruh hatinya terserap kedalam dunianya yang baru, dan karenanya lambat laun kehidupan iman \& ketaatan kepada TUHAN menjadi kendur. Di sisi lain, bahwa ajaran \& nasehat para tua-tua tdk mereka dengar dengan baik. Ajaran dan teladan hidupnya tidak cukup kuat untuk mempertahankan pola hidup benar sebagai umat Allah yang dikasihi-Nya. Sisi itu juga yang menyeret mereka kepada kompromi atau sinkristime iman. Interaksi social merka dengan bangsa-bangsa lain di sekitar tidak bisa menjadi teladan \& memberi dampak positif. Sebaliknya mereka silau dan terseret kepada budaya dan perilaku yang buruk. Pengajaran tentang kebaikan dan kebesaran Tuhan yang disampaikan secara verbal tidak bisa membendung arus kesuaman. Mereka tdak bisa memahami, karena semuanya hanya dalam ujud pengajaran, cerita atau wacana. Mereka gagal mememahami kebaikan Tuhan. (Hk. 2:10).

Pengenalan akan Tuhan menjadi sulit kalau hanya berupa pengajaran, sebab seluruh hati \& konsentrasinya terbelah dan kemudian dikalahkan oleh mammon. Yesus berkata tentang kebenaran ini: "Karena dimana hartamu berada, di situ juga hatimu berada." (Mat. 6:21)

Itulah sebabnya Malaikat Tuhan berkata kepada umat Israel di zaman hakaim-hakin sebagai berikut: 
Kesuaman: Bahaya Laten Terhadap Kehidupan Gereja Tuhan|5

"Telah kutuntun kamu keluar dari Mesir dan kubawa kenegri yang kujanjikan dengan sumpah kepada nenek moyangmu, dan Aku telah berfirman: Aku tidak akan membatalkan perjanjianku dengan kamu untuk selama-lamanya, tetapi janganlah kamu mengikat perjanjian dengan penduduk negeri ini; mezbah mereka haruslah kamu robohkan. Tetapi kamu tidak mendengarkan Firman-Ku. Mengapa kamu berbuat demikian?" (Hk. 2:1b-2).

Dalam konteks Laodekia, maka sesungguhnya jemaat di sana tidak menjadi jemaat seperti yang diharapkan. "Thus the church in Laodicea "was providing neither refreshment for the spiritually weary, nor healing for the spiritually sick. It was totally ineffective, and thus distasteful to the Lord. "9

Para pendeta gereja Kristen Nazarene menjawab masalah ini dari berapa sisi. Pertama, dari segi kepemimpinan-para pelayan Gereja, yang mulai kehilangan visi, pelayanan yang monotone, tidak ada kreativitas, kehilangan semangat dan merasa sudah nyaman, tak mau lagi menghadapi tantangan. Karena merasa nyaman, maka mereka tidak tertarik untuk berkarya lebih dari batas kewajaran. Bahkan ada yang menyebut telah kehilangan Roh dalam pelayanan mereka. Penulis, menyebut kondisi ini, mengutip seorang penulis dalam majalah Christianity Today, sebagai "spiritual bangkrupcy \& the lost of spiritual vitality."

Sedangkan dari sisi pengajaran, kadang hamba Tuhan tidak diperlengkapi dengan theologia Kristen yang memadai, karenanya mudah terseret arus berbagai pengajaran, tanpa mempu menyaring mana yang benar, mana yang salah. Pengajaran yang mereka berikan hanya membuat jemaat merasa senang, tetapi tanpa fondasi, tanpa isi dan umat tidak berakar dalam Kristus, tidak berakar dalam Iman \& firman (Kol.2:7). Hamba Tuhan malas belajar \& menggali firman Tuhan sehingga sabda Tuhan yang mereka sampaikan tidak bisa dicerna \& menyehatkan hidup kekristenan para pendengarnya.

Juga hal ini semakin parah karena hamba Tuhan tidak bisa menjadi teladan Iman, apa yang mereka ajarkan hanya menjadi wacana bagi hamba Tuhan itu sendiri. Mereka hanya mengandalkan logika, mengandalkan pengalaman, mengandalkan kefasihan lidah dan mengandalkan sarana-sarana yang ada. Bahkan penulis melihat di Melbourne, beberapa tahun lalui, ada hamba Tuhan yang terkadang hanya membeli khotbah-khotbah Minggu yang lengkap dengan power point dan ilustrasi-ilustrasi yang diperlukan. Pengajaran atau khotbahnya menawan, tetapi tidak mengandung nutrisi yang diperlukan.. Hamba Tuhan menjadi seperti Farisi \& Ahli Torat yang dikritik amat pedas oleh Tuhan Yesus (Mat. 23). Hamba Tuhan, mengutip kata-kata seorang gembala, kurang urapan oleh Roh Kudus, kurang dedikasi.

Yang kedua, Para hamba Tuhan GKN juga menjelaskan dari sisi umat, pertama, umat lebih mengutamakan hal-hal duniawi. Tidak ada waktu untuk belajar Firman Tuhan, terlalu sibuk, tidak bisa mengikuti pendalaman Alkitab, waktunya dihabiskan untuk mengurus perkaraperkara duniawi. Perkara rohani diabaikan, atau setidaknya di nomor duakan.

\footnotetext{
${ }^{9}$ Robert H. Mounce, The New International Commentary on the New Testament, The Book of Revelation, (Grand Rapids, Mi. William B. Eerdmans Publishing Company, 1977),99.
} 
Disamping itu, jemaat masih kompromi dengan dosa, dengan apa yang dianggap lazim di masyarakat. Judi, perselingkuhan dan juga merokok (hal ini dipandang kebodohan \& merugikan secara financial \& kesehatan tubuh, tidak ada unsur manfaatnya). Dengan kata lain warga jemaat sebagai orang Kristen, tetapi cara hidupnya duniawi (1 Kor. 3:1).

Lagi pula, banyak warga gereja sakit secara rohani. Marah kalau ditegur, ngambeg kalau mendengar khotbah yang keras, walaupun khotbah itu bersifat realistis \& alkitabiah. Mereka hanya mau makan yang enak, hanya mau mendengar yang menyenangkan. Khotbah atau ajaran yang bermutu mereka tolak, mereka hanya mau yang fast food- junk food, enak dirasa, menyenangkan di telinga, walaupun tidak menyembuhkan penyakitnya.

\section{Kesuaman Dalam Sejarah Israel}

Penulis, yakin bahwa Abraham-bapa orang beriman juga mengalami up and down dalam perjalanan imannya. Waktu Sara menawarkan Hagar menjadi gundiknya dengan tujuan memperoleh keturunan. Abraham bukannya tidak tahu kebenaran, dia juga bukan tidak tahu konsekuensi dari keputusan itu. Namun ternyata dia menerima saran \& usul isterinya yang tidak cerdas- bentuk ketidak percayaan kepada janji Tuhan, usulan yang tidak baik itu (Kej. 16:1-4). Kisah kehidupan rohani bangsa Israel pada zaman Hakim-hakim memberi gambaran yang jelas bagaimana bangsa itu sering berpaling dari Tuhan. Kisah yang terjadi dalam kitab Hakim-hakim seperti suatu siklus yang selalu berputar. Sewaktu bangsa itu makmur, aman, complacent, maka mereka lalu tidak serius dengan Tuhan, kompromi dengan bangsa sekitar, bahkan ikut menyembah berhala. Terkadang mereka ikut juga memraktekkan berbagai perilaku yang melawan hokum Tuhan. Ada yang memraktekkan untuk bertenung, ada penyembahan berhala, dan segala yang buruk terjadi.

Sewaktu kondisi kesuaman sudah menjadi kemurtadan, maka Tuhan menghukum bangsa Israel melalui raja-raja di dekat negeri mereka, ditindas, dimiskinkan, disengsarakan karena penjajahan. Sewaktu bangsa itu sadar dan Tuhan mengutus hakim untuk membawa mereka kembali kepada Tuhan, maka terjadilah pertobatan masal. Kemudian Tuhan pulihkan keadaan, kemakmuran, keamanan, kedamaian ada di seluruh negeri. Namun lambat laun bangsa Israel menjadi suam, teroccupied oleh dunia dan kemudian membelakangi Tuhan. Demikian seterusnya suatu siklus perjalanan yang selalu berputar semacam itu (Hk. 2-8).

Pada zaman raja-raja, hal yang sama juga terjadi. Bangsa Israel jatuh bangun-up and down karena kesuaman yang menjadi makin parah dan akhirnya menjadi kemurtadan, bahkan ada yang mempersembahkan anaknya untuk dikorbankan dalam api, (2 Rj, 16:3; 2 Rj 17: 17) Inilah praktek agama kafir yang diwarnai kebodohan dan kengerian. Telah hilang nurani dan akal budi umat itu sebagai manusia.

Akhirnya Samaria, kerajaan Utara yang terdiri dari sepuluh suku, terlebih dahulu membayar harga yang amat mahal. Negeri itu ditaklukkan. Samaria, ibu kota negeri itu diluluhlantakkan dan akhirnya bangsa itu dibuang ke Asyur (2 Rj.17:6). Finley mengomentari penyebab kejatuhan Israel karena kesuaman. Berdasarkan 2 Raja-raja 17 dia memberi tema: "The anatomy of false faith: "Lip service to God (17:32); Practical devotion to other interests 
Kesuaman: Bahaya Laten Terhadap Kehidupan Gereja Tuhan|7

(17:33); unchanged lives (17:34) forgotten vows (17:35) dan forsaken heritage of the past $(17: 36) " 10$

Kemudian paska kejatuhan Kerajaan Israel, maka kerajaan Yehuda masih bisa bertahan. Ada raja yang baik, ada yang buruk. Raja Yehuda yang bernama Hiskia melakukan reformasi \& restorasi keagamaan. Paskah dirayakan dan segala yang baik dilakukan. Walau demikian Hizkia juga menjadi congkak dan egois dengan memamerkan isi istanya kepada utusan Babil (2 Raja2 20:12-21). Oleh perbuatannya itu nabi Yesaya datang untuk menegur dan memberitahukan bahwa semua barang kebanggaan yang dipamerkan besok akan diangkut oleh musuh.Berikutnya, Raja Menasye melakukan kekejian-kekejian dan mencurahkan darah orangorang yang tidak bersalah dan melakukan hal-al yang jahat. Karena kelakuannya itu bangsa Yehuda juga terseret menjadi suam, dan berbuat jahat (2 Rj. 21:16)

Kemudian Menasye digantikan oleh raja Amon yang hidup dan perilakunya mengikuti teladan buruk ayahnya. Raja ini juga menyembah berhala dan meninggalkan Tuhan dan tidak hidup menurut kehendak Tuhan (2 Raj. 21:21-22). Bahkan pada zamannya, di negeri "theokratis" itu terjadi pertumpahan darah yang menyedihkan.

Selebihnya, ada raja Yosia yang baik dan berbakti kepada Tuhan. Pada zamannya maka kitab Torat itu ditemukan. Hal itu memberikan indikasi bahwa Torat itu diabaikan, Firman Tuhan dilupakan. Sama seperti Hizkia, Yosia melakukan reformasi keagamaan termasuk memperbaiki bagian-bagian bait Suci yang rusak termakan usia (2 Raja2 22:1-20). Dia juga melakukan barbagai penataan sehingga kehidupan rohani dan moral keagamaan bangsa Yehuda menjadi baik kembali. Dia merayakan Paskah, menghancurkan dan membuang semua bentuk berhala dari negeri (2 Rj. 23:24).

Sesudah Raja Yosia, masih ada empat raja yang memerintah Yehuda, tetapi semu raja itu melakukan apa yang jahat di mata Tuhan. Bahkan raja terakhir yang bernama Zedekia, ia juga melakukan apa yang jahat di mata Tuhan (2 Rj. 24:19). Akibatnya, Zedekia ditangkap, disiksa, anak-anaknya dibunuh di depan matanya. Kemudian matanya dicukil dan dibelengggu serta dibawa ke Babil (2 Rj. 25:4). Akhirnya Yerusalem juga jatuh. Tembok-tembok kota Yerusalem diruntuhkannya. Bait Allah, kebanggan bangsa itu, dibakar, semua barang-barang kudus diangkut oleh Nebukadnezar ke Babil. Orang-orang Yehuda banyak yang mati dalam perang dan sisanya ditawan ke Babil, sebagai buangan atau tawanan. Semua berawal dari kesuaman yang tidak diatasi dengan pertobatan yang sejati.

\section{Kesuaman Dalam Sejarah Gereja}

Penulis membatasi pembahasan ini hanya secara garis besar tentang apa yang terjadi kepada Gereja Tuhan yang kudus dan am. Pada masa gereja mula-mula, jemaat Tuhan bergumul

${ }^{10}$ Harvey E. Finley, Beacon Bible Commentary,Vol. 2; The Book of Kings (Kasas City: Beacon Hill Press of Kansas City,1965),475. 
dengan banyak situasi, termasuk terbatasnya resources dan juga penganiayaan gereja oleh bangsa Yahudi dan kemudian oleh kekaisaran Romawi.

Namun mulai tahun 311, Konstantinus, kaisar Romawi pada zaman itu, menjadi (mengaku) orang Kristen. Konsekuensinya adalah gereja medapatkan kedamaian bahkan Kekristenan diangkat bukan saja sebagai agama resmi, malah dijadikan sebagai agama negara. Dalam satu sisi, ini seolah menjadi rahmat bagi gereja, penganiayaan yang massif \& sistimatis terhenti karenanya. Namun pada sisi yang lain banyak yang menilai bahwa mulai saat itu gereja masuk dalam perangkap duniawi.

Dalam kenyataannya, mulai saat itu, Gereja mendapat dukungan financial, sehingga gedung gereja dibangun megah di mana-mana. Gereja mulai menikmati complacency dan sama seperti yang terjadi pada orang Israel, maka gereja mulai mengalami kemerosotan secara kualitatif. Ada banyak kompromi dengan kekafiran, gereja sakit dari dalamnya. Pada zaman Konstantinus, umat beribadah dg bebas, tetapi pemerintahannya " brought a mixed blessing. it has its evil as well as its good aspect. Multitudes took up with Christianity who had no experience of conversion and of the work of the Holy Spirit in the human heart, Quality was sacrificed to quantity. ${ }^{11}$

Tidak lama sesudah itu, kekristenan menyebar, termasuk ke Inggris. Juga berkuasalah para Paus yang bergandengan dengan para Kaisar. Kaisar adalah simbok pimpinan duniawikepala kekaisaran, sedangkan Paus adalah symbol pimpinan rohani-gereja. Dalam perjalanannya, sampai kaisar harus tunduk kepada Paus sebagai pimpinan Rohani, atau sebaliknya. Akibatnya sering ada konflik atas keduanya dan dampaknya yang buruk bagi kehidupan gereja.

Situasi itu membawa gereja masuk dalam suatu era yang panjang dan menyedihkan, yang dalam hal ini lambat laun masuk suatu zaman yang kita sebut sebagai abad pertengahanabad kegelapan (dark ages) yaitu antara tahun 1049- 1294. Perjalanan gereja justru makin tidak benar, dimana sering Gereja dikuasai oleh kaisar. The state exersized control over the Church by selling ecclesiastical dignities, or the practice of simony and by the investiture of bishop and abbots. ${ }^{12}$ Tidak heran pada masa itu, para pimpinan gereja diisi bukan oleh orang-orang yang memenuhi kualifikasi rohani dan kecakapan, tetapi oleh orang-orang yang punya uang untuk menyuap. Akibatnya Gereja telah kehilangan "Roh" dan identifikasi sebagai Tubuh Kristus yang kudus.

Orang-orang yang berusaha memperbaiki situasi ini malah harus membayar harga yang mahal. Mereka ditangkap dan diadili oleh gereja sebagai bidat, karena gereja mempunyai pengadilan agama yang disebut inkuisisi (inquisition). Maksudnya adalah untuk membasmi apa yang namanya ajaran sesat (heresy). Inilah bentuk kesewenangan Gereja yang menghukum dengan semena-mena orang yang dianggap menyampaikan atau mengikuti 'ajaran sesat' atau sejenisnya. ... in the name of religion applying torture to countless helpless victims, heretics, and repute witches and pronouncing upon them a sentence, which, they knew involved perpetual imprisonment or death in the flames. ${ }^{13}$.

\footnotetext{
${ }^{11}$ S.M Houghton, Sketches from Church History (London:The Banner of Truth Trust,1980), 21

12 Philip Schaff, History of the Christian Church, Vol. 2, part 1. (New York:Charles Scribner's Sons,
} $1925), 45$.

${ }^{13}$ Ibid, 515. 
Kesuaman: Bahaya Laten Terhadap Kehidupan Gereja Tuhan |9

Syukur karena ada tokoh-tokoh yang secara berani dan konsisten untuk menyuarakan kebenaran dan melakukan reformasi terhadap gereja, walaupun ada orang-orang yang demikian sudah dihukum mati oleh pengadilan agama tersebut. Mereka itulah pembuka jalan menuju Reformasi Gereja. Sebut saja nama-nama agung yang hadir sebelum Reformasi, orang2 Weldenses, yakni pengikut Peter Waldo di Perancis di awal abad 12. Mereka setelah memahami Firman Allah, menjadi sungguh-sungguh dalam iman, bersaksi \& sering menyerang ajaran gereja yang penuh tahyul. Mereka adalah orang Kristen sungguh-sungguh dan kemudian dilarang oleh gereja. Bahkan dibunuh dengan kejam atas perintah Paus Gregorius IX. ${ }^{14}$

John Wycliffe, dari Inggris juga ingin melakukan reformasi bagi gereja dan ajaran gereja. Dia awalnya didukung oleh raja Inggris, tetapi kemudian, karena perlawanan dari para iman, maka raja menarik dukungannya. Dia dan para pengikutnya mengalami penganiayaan yang berat, dan hasilnya dia bisa menterjemahkan Alkitab dalam bahasa Inggris. ${ }^{15}$ Kebencian kaum imam terhadap Wiyclffe sungguh diluar batas, bahkan setelah kematiannya, kuburannya digali, dan tidak lagi dikuburkan, tetapi kemudian dibakar dan abunya dilarung di sungai Swift.

John Huss, setelah membaca tulisan Wycliffe sangat merindukan untuk memurnikan gereja dan membawa kembali kepada ajaran Perjanjian Baru. Dia sangat melawan begitu banyak tahayul dalam gereja. Buku-buku yang dia tuliskan dibakar habis oleh Uskup Prague. Huss tetap pada pendiriannya untuk mentaati Alkitab, dan ajaran yang tidak sesuai dengan Alkitab adalah antikristus. Huss diekskomunikasikan oleh Paus, dan tidak boleh mendapat pelayanan rohani (interdict). Semua bukunya dibakar, Huss disiksa dan akhirnya dihukum mati dengan cara yang amat sadis.Demikian juga orang-orang yang mendukung dan mengikut Huss jaga diperlakukan dengan penganiayaan.

Jerome Savonarola dari Italia juga berusaha memperbaiki keadaan masyarakat dan kehidupan gereja. Dia bukan reformator secara doctrinal, tetapi manusia yang mengaku Kristen dengan segala kesungguhan. Dia adalah penguasa di Florence, Italia. Dia ingin menjadikan kota Florence sebagai model masyarakat Kristen dengan Tuhan sendiri sebagai Raja dan Injil sebagai Hukum yang berlaku. ${ }^{16}$ Karena dia tetap pada pendiriannya dan melawan Paus dan para imam yang jahat, maka dia akhirnya dikenakan hukuman mati dengan cara dibakar pada tahun 1498 .

Gerakan reformasi terjadi, gereja serta doktrinnya dikembalikan kepada ajaran Injil pada tanggal 31 Oktober 1517. Gerakan itu menyebar, menyemarakkan kehidupan gereja kembali kepada ajaran Perjanjian Baru. Pengaruhnya sangat kuat, tidak terkecuali di Inggris dan Skotlandia disamping Belanda, Jerman dan Perancis. Namun sejarah juga membuktikan bahwa hidup orang Kristen secara rohani dan social kembali merosot, seperti siklus yang terjadi pada bangsa Israel. Kemudian lahirlah gerakan kebanguan rohani oleh John Wesley dan Charles Wesley pada abad 18, baik di Inggris maupun kemudian ke Amerika. ${ }^{17}$ Siklus ini tetap menjadi fenomena kehidupan gereja hingga masa kini.

\footnotetext{
${ }^{14}$ S.M. Houghto, 63.

15 Ibid, 67.

${ }^{16}$ Ibid.73.

${ }^{17}$ Earle E. Cairns, Christianity through the Centuries, A History of Christian Church (Grands Rapid, Michigan: Zondervan Publishing House, 1981), 383.
} 


\section{Bagaimana Membendung \& Mengatasi Arus Kesuaman: Pemuridan}

Berkaca dari apa yang diajarkan oleh Alkitab, dalam Perjanjian Lama, Musa menasehatkan supaya umat mendapat pengajaran Firman sedemikian intensif dan berkesinambungan (Ul. 6:1-4-9). Yesus mengajakan bahwa Firman Allah, bukan saja dimengerti, tetapi juga harus ditaati seperti orang yang bijaksana mendirikan rumah. (Mat.7:26) Kalau Firman hanya menjadi wacana, maka orang akan pintar berargumen dan dan ujungnya menjadi suam. Paulus mengajar kita agar umat berakar dan dibangun di dalam Kristus (Kol.2:7)

Berdasarkan hal itu, maka untuk membendung dan mengatasi kesuaman, gereja harus melakukan apa yang namanya pemuridan. Suatu kurikulus pengajaran yang memadai, ringkas, komprehaensif, dan alkitabiah yang meliputi:

Arti menjadi orang Kristen, itu berarti harus mengalami pertobatan dan sekaligus pengakuan iman. Juga apa artinya menjadi murid Kristus, yang selalu haus untuk belajar Firman Tuhan, dengar-dengaran kapada Sabda Tuhan. Bagaiman berdoa, mengapa berdoa, hrs mmenjadi suatu gaya hidup. Bagimana bersaksi, mengapa harus bersaksi, sebagai ujud gereja Tuhan yang missioner. Dengan kerinduan \& upaya bersaksi, maka yang bersangkutan bisa terus mewaspadai dirinya untuk hidup benar.

Kemudian apa arti Roh kudus, apa artinya dipenuhi oleh Roh, mengapa mutlak dan bagaiman caranya dipenuhi oleh Roh. Yang terakhir, usul penulis adalah mengajar pentingnya gereja, dan mengapa wajib mendukungnya dengan segala resources-- waktu, talenta dan harta.

Dengan pemuridan yang seperti itu, maka orang Kristen akan menjadi umat yang berakar dalam Firman, bebas dari apa yang namanya "biblical illiteracy" alias buta Alkitab. Dengan itu, maka makna utama Injil bisa diyakini, dihayati dengan sungguh-sungguh. Melalui

pengajaran, maka hidup rohaninya terpelihara sehingga terbebas dari apa yang disebut "spiritual bankruptcy" dan tetap bisa memelihara vitalitas rohani untuk melawan arus duniawi dan kesuaman. Disamping itu visi pemberitaan Injil tentap menyala di hati umat. 
Kesuaman: Bahaya Laten Terhadap Ke hidupan Gereja Tuhan|11

\section{Kesimpulan}

Kesuaman adalah penyakit rohani yang disebabkan oleh kurangnya pemahaman Firman Tuhan, keristenan tanpa pertobatan dan hidup Kristen sembarangan tanpa komitmen. Hal itu terjadi karena pemimpin yang tanpa visi, malas dan egois. Juga karena umat yang silau terhadap dunia, menjadi hamba mammon dan tidak mau diajar.

Jawaban atas semua masalah yang kronis dan mengancam hidup gereja Tuhan itu sederhana, walaupun tidak mudah dilaksanakan, tetapi pasti bisa dilakukan. Solusinyanya dapat diringkaskan dengan dua kata: pertobatan \& pemuridan. 


\section{DAFTAR PUSTAKA}

Clarke Adam, The Holy Bible, Old and New Testament: Commentary \& Critical Notes, Vol. VI.London:Ward, Lock \& Co., Warwick House,tt, Tafsir Wahyu 3:15

Cairns Earle E., Christianity through the Centuries, A History of Christian Church Grands Michigan Rapid,: Zondervan Publishing House, 1981

Earle Ralph, Beacon Commentary, Vol. 10, The Book of Revelation, Kansas City: Beacon Hill Press of Kansas City, 1967

Finley Harvey E., Beacon Bible Commentary,Vol. 2; The Book of Kings Kasas City: Beacon Hill Press of Kansas City, 1965

Hornby A.S., E.V. Gatenby; H. Wakefield, The Advanced Learner's Dictionary of Current English London: The English Language Book Society and Oxford University Press, 1962

Houghton S.M, Sketches from Church History London:The Banner of Truth Trust,1980

Schaff Philip, History of the Christian Church, Vol. 2, part 1. New York:Charles Scribner's Sons, 1925

Mounce Robert H, The New International Commentary on the New Testament, The Book of Revelation, Grand Rapids, Mi. William B. Eerdmans Publishing Company, 1977

Poerwodarminta WJS, Kamus Umum bahasa Indonesia, Jakarta, Balai Pustaka,1987

Paterson Christina, 3 Signs You Might be a Lukewarm Christian, WWW.ibelieve.com, Feb. 15, 2017. 